\title{
Scientific Production on Technological Cooperation Networks in Biotechnology sector
}

\author{
João Marcos Silva de Almeida ${ }^{1}$, Priscila Rezende da Costa ${ }^{1}$, Angélica Pigola ${ }^{1,}$ *, Claudia Teresinha Kniess ${ }^{2}$, Geciane \\ Silveira Porto ${ }^{3}$, Alex Fabiane de Paulo ${ }^{4}$, Leonardo Vils $^{1}$, Marcos Rogério Mazzieri ${ }^{1}$, André Moraes dos Santos ${ }^{5}$

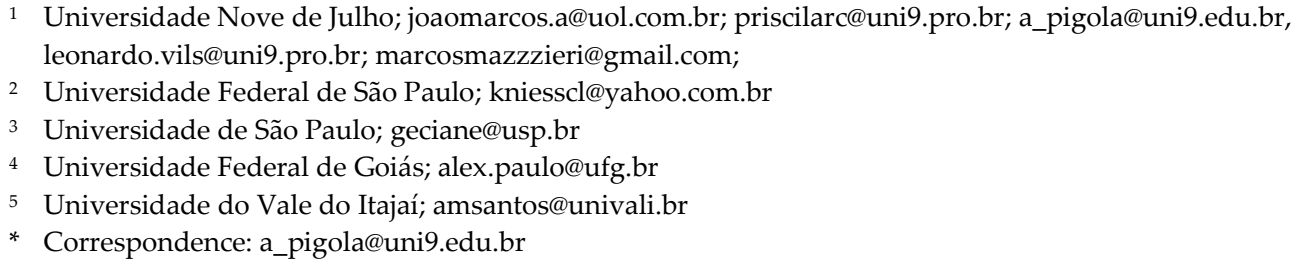

\begin{abstract}
The present study aims to analyze scientific production about technological cooperation networks in biotechnology sector, based on bibliometrics network analysis. We used the Gephi software to identify groups of partnerships, proving that the cooperation relationship is a practice used, resulting technological development. Findings identify that in the path for new resources that complement skills and competences universities are an important player in this cooperative ecosystem, and The United States is a large hub, with an extensive network of global cooperation. A strong role of its researchers in the publication of scientific articles in cooperation is highlighted. This study contributes to the advancement of the discussion about cooperative networks, as well as to the development of policies aimed at the biotechnology sector advancements.
\end{abstract}

Keywords: Technological Cooperation Networks; Biotechnology sector; Bibliometrics; Social Network Analysis.

\section{Introduction}

Companies are increasingly challenged to remain competitive and innovative in their markets. The complexity of the organizational context and the dynamics of the markets have encouraged companies to seek new organizational arrangements for their business models.

The biotechnology sector [1] relates to open innovation because it uses external sources of knowledge to improve its capacity to innovate through collaborative efforts. These efforts are key factors for biotechnology industry development and its business management innovative capacity and are intensified through mutual trust [2].

Biotechnology companies develop themselves in a complex and dynamic system of cooperation networks, formed by many actors such as, universities, research institutes, investment funds, government agencies, pharmaceutical laboratories, and other partnerships [3]. These actors use a variety of arrangements to achieve a dynamic knowledge flow through an intensive of professionals' relationships into different directions.

The impact of cooperation for innovation is not only mediated by the proximity of these actors, but also by their level of networks intensity from the cooperation [4]. Therefore, we pursue to identify in this bibliometric study which level of cooperation exist in the literature and the relevance of technological cooperation networks for the biotechnology sector because there is no convergence regarding the systematization of scientific production and the configuration of research cooperation networks for technological development. 
Research on the association between networks of technological cooperation and patents in biotechnology is nominal [4,5], and few studies consider the intensity and the relationship of such networks based on bibliometric data $[6,7,8]$. We intend to contribute to the advancement of scientific knowledge from the mapping of the theoretical-conceptual framework, as well as to the development of policies aimed at the biotechnology sector advancements.

\section{Theorical background}

Biotechnology sector has in its essence a tremendous potential to innovate, and operates in several sectors, such as health, agriculture, environment, and others. Its importance to develop regions and countries, in general, can be illustrated by the capacity of promoting national development generating jobs and supporting the economies. Modern biotechnology is characterized by the complexity and multidisciplinary of the knowledge and the high dependence on research, and high risks involved in the development of a new discovery [1]. For organizations that using biotechnology the relationship between knowledge management and business performance is distinctive [9].

The development of biotechnology sector is causally related to the establishment of inter-organizational partnerships and consequently, the intensification of cooperation networks which allow companies and / or institutions to have access to specific knowledge sources [10]. Thus, interorganizational cooperation along the value chain is essential for cocreation and innovation [11], as well as for knowledge transferring [12].

Cooperation networks emerged in organizational field to group attributes that allow companies to adapt to competitive and dynamic environment [13]. Thus, networks contribute to aggregate complementary knowledge and skills [14] and gain competitive advantage [15].

Cooperation also appears as the alternative for companies to acquire new resources and knowledge in the search for innovation. Chesbrough [16] conceptualizes this model as "open innovation". In the current paradigm of open innovation (OI), research on collaborations between actors are considered especially important for the development of science and technology [17,18,19].

The term "open innovation" was created with the purpose of defining the network nature of innovation mechanisms. Open innovation in this study is considered as a paradigm that assumes that companies can and should use external ideas, as well as internal ideas to seek and make advancements in technology [17]. The theory of open innovation provides important insights into intensified role of accessing knowledge and networks to facilitate innovation through innovative processes $[16,17,20,21]$. Chesbrough and Bogers [22] in more recent definitions, emphasize that the main feature of innovation is the organization's ability to manage these knowledge flows.

Companies participating in multiple cooperation networks can represent a complementarity in various projects in which they are involved, benefiting strategic choices for innovation [23]. Bengtsson and Sölvell [24] demonstrate that the intensity of interaction in networks is positively correlated to the generation of innovations. Conversely, companies that are not engaged in cooperation and knowledge exchange limit their knowledge base [25]. Recent literature also highlights biotechnology companies operating naturally in collaborative networks maintaining partnerships with universities to increase their innovation capacities [26].

Torres-Freire et al. [27] observed that the economic activity involving biotechnology has high technological intensity and does not develop without communication between private (companies), public (governments/agents), and academic (institutions / universities) sectors. This integration refers to "Triple Helix" concept, which proposes a dynamic relationship between state and science conducted in universities and materialized by 
technology developed in companies [28] (p. 112). A technological cooperation network is essential for companies in the biotechnology sector, given the competitive and intensive nature of knowledge, making these networks the main sources of innovation [1].

Many countries have introduced a series of measures to strengthen links between industries, universities, and public research institutes focusing on achieving innovation, technological development, and improving national economic performance [29].

\section{Methods}

Bibliometric studies emerged as an accurate method to assess the contribution of an article to the advancement of knowledge. According to Narin et al. [30], the basic principle of bibliometric analysis is the quantification of scientific publications by means of technical performance parameters for determining productivity. Hence, this research was completed on the Web of Science portal, in the period of June and July 2019, using keywords and terms involving "networks of technological cooperation and patents in biotechnology". The research was conducted by the Web of Science Core Collection, allowing research coverage in the Science Citation Index Expanded (SCIE), Social Sciences Citation Index (SSCI), and Arts \& Humanities Citation Index (AHCI), published from 1988 until 2019.

The Linguee dictionary, developed by Gereon Frahling, was used as a tool to support the choice of words, terms, and expressions. This tool presents characteristics that distinguish it from a traditional dictionary, as it not only shows the entries and their respective translations, but also generates a Parallel Corpus, containing the searched word or phrase. The phrases that comprise the corpus are found by programs called network crawlers (web crawlers). The trackers are updated as they allow the dictionary to constantly have new data [31].

The construction of the search expression of this research was formed by associating the words "cooperation" and "collaboration", using the boolean "OR" between them, since both words are commonly used in articles that refer to cooperation. The words "network" and "technological" were added to the search expression and the word "patent", with the special character $\left(^{*}\right)$ added to expand the search and identify possible variations aiming to highlight the cooperation between the actors in this research field. As final objective, we added "technological cooperation networks" to the biotechnology segment, using the boolean "AND" so that it could verify the simultaneous occurrence of the other terms in relation to the biotechnology segment. To summarize, the search term used was: ("cooperat * or collabor * or network * or technol ${ }^{*}$ ") or patent *) and biotec *.

Gephi software, version 0.9.2, analyzed social networks and was created focusing on the construction, visualization, and analysis of technological cooperation and patents in biotechnology, considering the bibliometric data obtained [32]. Social Network Analysis (SNA) is a powerful approach tool to get answers about behavior between individuals or organizations, as well as to understand patterns and main influencing agents within a theme [33]. It explores the relationship ("loops", "arcs", or "edges") between the actors (known as "we" or "vertices").

Initially, a bipartite network was built, in which the nodes are the organizations that are connected through other nodes that represent the titles of the works. In a second step, the nodes with the names of the articles were transformed into edges that connected the organizations, forming the final network. Modularity, grade, weighted average grade, and PageRank [34] were the statistics adopted for the necessary analyses and conclusions [35]. And finally, for the construction of networks, data such as title, authors, and address (institution and country) of the authors were exported and treated with Microsoft Excel resources, for authorship data could be obtained. 
At this stage of the research, it was possible to identify, from the analysis of social networks, the relationship between organizations (universities, research centers, or companies) in which the research was developed. This means that the actors were recognized as hubs in the systematized cooperation networks or as bridges between the different subnets [36].

\section{Results}

After carried out a detailed analysis of the main publications on the theme, the networks were built so that the work of the main researchers about "networks of technological cooperation and patents in biotechnology" could be evidenced.

\subsection{Publications and citations}

The search criteria used in this study yielded a total of 666 articles. The articles have a total of 10,085 citations distributed over the period of the study and an average of 22.2 publications and 336,17 citations per year (Figure 1). We observed the majority of publications among 2011 until 2014. After 2000, publications were practically over 20 editions per year showing a steadiness.

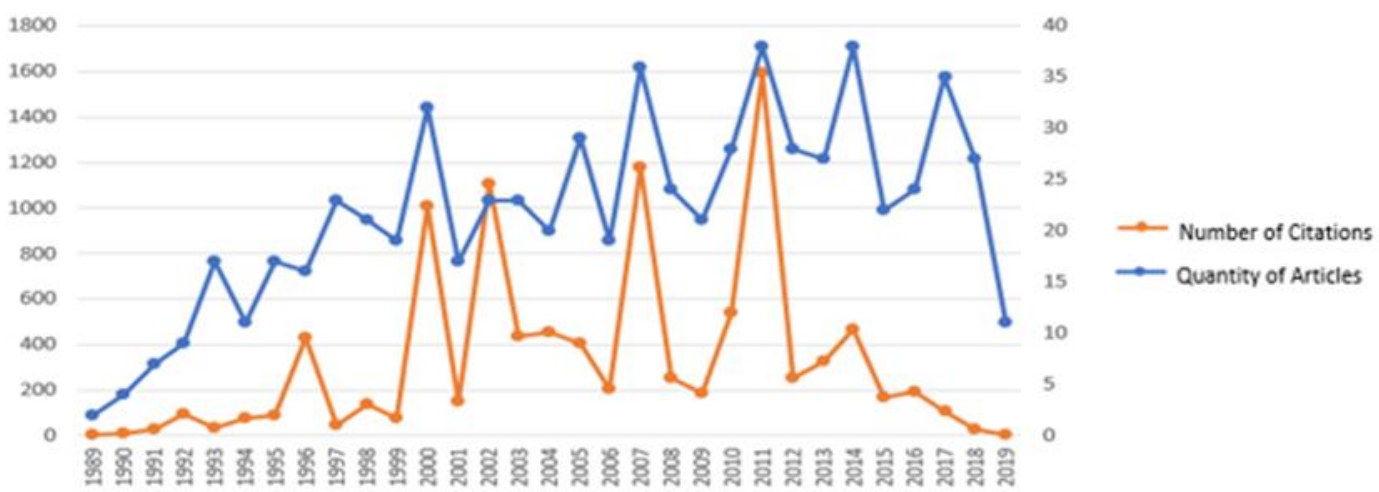

Figure 1. Evolution of articles and citations. Source: Based on processed data by the authors

\subsection{Countries and publications}

The United States leads the ranking with 205 publications, followed by England (60 publications), Germany (49 publications), and Italy (31 publications), make up a representative block in scientific production in technological cooperation networks and patents in biotechnology.

We identified, the strength of cooperation assessed by the number of cooperative works, that is, in co-authorship, each country has. This indicated the connection and interaction that a country has with other countries in collaborative scientific research. The sharing of information, the union of competences, and the efforts of researchers in the search for common goals boost the production of knowledge [37] and it is possible to claim that co-authorship in scientific publications is an indicator of collaboration [38].

According to Capaldo [39], the strength of the relationship can be expressed in terms of the total duration of the relationship, frequency, or intensity of the collaboration. It is assumed that the more lasting, frequent, or intense the collaboration, the greater the strength of the relationship. According to the Organization for Economic Co-operation and Development - OECD [40], the strength of the relationship is considered an important variable, since it positively affects trust between partners and the transfer of knowledge. The United States has the largest number of works (177) and the highest number of citations (3926) and the largest number of cooperative works (99). Followed by Canada with 36 cooperative works, and France with 30 (Table 1). 
Table 1. Ranking of the top 10 countries that work the most in cooperation.

\begin{tabular}{cccc}
\hline Countries & Number of articles & Citations & Articles in cooperation $^{\mathbf{1}}$ \\
\hline United States & 177 & 3926 & 99 \\
Canada & 33 & 1521 & 36 \\
France & 27 & 497 & 30 \\
China & 26 & 192 & 29 \\
England & 47 & 677 & 25 \\
Belgium & 21 & 369 & 24 \\
Taiwan & 24 & 241 & 24 \\
India & 22 & 136 & 22 \\
Netherlands & 20 & 211 & 19 \\
Germany & 39 & 498 & 17 \\
\hline
\end{tabular}

${ }_{1}^{1}$ are scientific articles co-authored showing the scientific cooperation between authors from different institutions and nationalities. Source: Based on processed data by the authors

\subsection{Articles, authors, and journals}

To substantiate the relevance of publications based on scientific articles, Table 2 displays the first 10 articles, authors and their respective journals with their respective citations and average citations per year. The largest number of citations (1088) is represented by the effort of a group of 14 authors, in an article published in the Nucleid Acids Research Journal, in 2011. The research refers to the DrugBank database, with information on bioinformatics and chemo-informatics, which combines detailed drug data with comprehensive information on possible drug targets. In second, is the Management Science journal, published in 2007, with the second highest number of citations (515).

Table 2. Ranking of the first 10 articles with the respective citations

\begin{tabular}{|c|c|c|c|}
\hline Authors & Journal & Citations & $\begin{array}{c}\text { Average } \\
\text { Year }\end{array}$ \\
\hline $\begin{array}{l}\text { Knox, C.; Law, V.; Jewison, T.; Liu, P.; Ly, S.; } \\
\text { Frolkis, A.; Pon, A.; Banco, K.; Mak, C.; } \\
\text { Neveu, V.; Djoumbou, Y.; Eisner, R.; Guo, A.; } \\
\text { Wishart, D. [41] }\end{array}$ & $\begin{array}{l}\text { Nucleic Acids } \\
\text { Research }\end{array}$ & 1088 & 120.89 \\
\hline Schilling, M.; Phelps, C. [42] & $\begin{array}{l}\text { Management } \\
\text { Science }\end{array}$ & 515 & 39.62 \\
\hline $\begin{array}{c}\text { Zucker, L.; Darby, M.; } \\
\text { Armstrong, J. [43] }\end{array}$ & $\begin{array}{c}\text { Management } \\
\text { Science }\end{array}$ & 438 & 24.33 \\
\hline $\begin{array}{l}\text { Giddings, G.; Allison, G.; } \\
\text { Brooks, D.; Carter, A. [44] }\end{array}$ & $\begin{array}{c}\text { Nature } \\
\text { Biotechnology }\end{array}$ & 323 & 16.15 \\
\hline Baylis, A. [45] & $\begin{array}{c}\text { Pest Management } \\
\text { Science }\end{array}$ & 276 & 13.8 \\
\hline Gittelman, M.; Kogut, B. [46] & $\begin{array}{l}\text { Management } \\
\text { Science }\end{array}$ & 274 & 16.12 \\
\hline $\begin{array}{l}\text { Blumenthal, D.; Causino, N.; } \\
\text { Campbell, E.; Louis, K. [47] }\end{array}$ & $\begin{array}{c}\text { New England } \\
\text { Journal of Medicine }\end{array}$ & 220 & 9.17 \\
\hline Ziedonis, R. [48] & $\begin{array}{l}\text { Management } \\
\text { Science }\end{array}$ & 215 & 13.44 \\
\hline Shane, S. [49] & $\begin{array}{l}\text { Management } \\
\text { Science }\end{array}$ & 196 & 10.89 \\
\hline
\end{tabular}


Broothaerts, W.; Mitchell, H.; Weir, B.; Kaines,

S.; Smith, L.; Yang, W.; Mayer, J.; Roa-Rodriguez, C.; Jefferson, R. [50]

Source: Based on processed data by the authors

\subsection{Journals, articles, and citations}

We conducted a joint analysis of the number of publications, the number of citations related to journals (Table 3), since traditionally the evaluation of the number of published works, initially widely accepted and used, is no longer sufficient as a way of assessing the vigor of the scientific production. The quality of publications is also seen as a differential factor. Thus, the evaluation of the interest aroused by the work or line of research within the scientific community is highlighted, a factor that reflects the number of citations made to a given work [51] and where published. The Management Science, Scientometrics, Nature Biotechnology, and Technovation journals have the highest citation rates and the largest number of articles.

Table 3. List of journals, articles, and citations

\begin{tabular}{ccccc}
\hline Journals & $\begin{array}{c}\text { Number of } \\
\text { citations }\end{array}$ & $\begin{array}{c}\text { Ranking } \\
\text { citations }\end{array}$ & $\begin{array}{c}\text { Number of Ranking } \\
\text { articles }\end{array}$ & \begin{tabular}{c} 
Articles \\
\hline Management Science
\end{tabular} \\
\hline Nucleic Acids Research & 1802 & 1 & 10 & 9 \\
\hline Scientometrics & 768 & 3 & 51 & 50 \\
\hline Nature Biotechnology & 403 & 4 & 11 & 7 \\
\hline Technovation & 369 & 5 & 14 & 5 \\
\hline Management Science & 301 & 6 & 1 & 91 \\
\hline New England Journal of Medicine & 225 & 7 & 1 & 92 \\
\hline Nature & 188 & 8 & 3 & 34 \\
\hline Biotechnology and Bioengineering & 156 & 9 & 2 & 51 \\
\hline Journal of Product Innovation Mgmt & 139 & 10 & 2 & 52 \\
\hline
\end{tabular}

Source: Based on processed data by the authors

\subsection{Countries and institutions}

Observing how countries, institutions, and authors relate in network with the respective nodes and edges, it was found that level 1, the nodes are the authors, and the edges the scientific articles produced in co-authorship. Level 2 is the nodes represented by the institution to which the authors are linked, and the edges are the scientific articles produced in co-authorship. In level 3 we have the country to which the authors belong, and the edges are the institutions where the scientific articles in co-authorship are produced (Figure 2).

The structural position of actors within a network is an important indicator of their ability to articulate with other actors, as well as their ability to openly seek innovation $[52,53]$. The centrality that an actor has within a network system demonstrates its importance or prominence individually in the formed network [54,55]. In the field of innovation studies, actors with high centrality can be considered the most "open innovators" in innovation systems or knowledge networks [56]. 


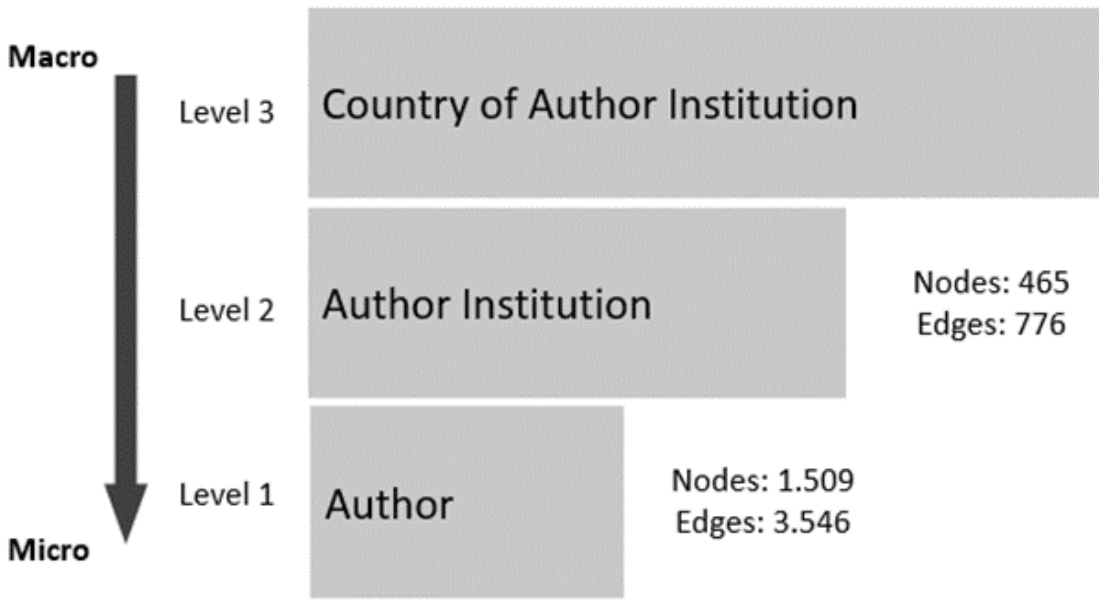

Figure 2. Granularity Map. Source: Based on processed data by the authors

The United States forms a great hub, the country concentrates its research and correlates with practically the whole world, with highlight from the intense cooperation formed by Belgium, England, Germany, China, and Canada. The sub-hub that Saudi Arabia forms with other countries in the Middle East is noteworthy. This empowers this country a lot regarding knowledge about patents and biotech. We highlight the clusters of Holland and Spain, which in a way, shows the affinity of cooperation (and possibly knowledge) between these different countries. The detailed ranking of 15 main countries that have the largest publications, confirm that strength of The United States is unambiguous, as they include the largest number of articles and the largest number of citations followed by countries have already identified in the network (Table 4).

Table 4. Ranking of countries, publications, and citations

\begin{tabular}{|c|c|c|c|c|}
\hline Country & $\begin{array}{c}\text { Number of } \\
\text { citations }\end{array}$ & $\begin{array}{l}\text { Ranking } \\
\text { citations }\end{array}$ & $\begin{array}{c}\text { Number of } \\
\text { Articles }\end{array}$ & $\begin{array}{c}\text { Ranking } \\
\text { articles }\end{array}$ \\
\hline USA & 4498 & 1 & 177 & 1 \\
\hline Canada & 1572 & 2 & 33 & 4 \\
\hline England & 722 & 3 & 47 & 2 \\
\hline Germany & 526 & 4 & 39 & 3 \\
\hline Italy & 500 & 5 & 29 & 5 \\
\hline Wales & 396 & 6 & 5 & 21 \\
\hline Belgium & 378 & 7 & 21 & 10 \\
\hline Taiwan & 260 & 8 & 24 & 8 \\
\hline Australia & 245 & 9 & 14 & 13 \\
\hline Spain & 243 & 10 & 11 & 16 \\
\hline France & 240 & 11 & 26 & 6 \\
\hline Netherlands & 218 & 12 & 20 & 11 \\
\hline China & 210 & 13 & 26 & 7 \\
\hline Brazil & 191 & 14 & 20 & 12 \\
\hline India & 147 & 15 & 22 & 9 \\
\hline
\end{tabular}

Source: Based on processed data by the authors

Table 5 shows the distribution of scientific articles made in cooperation by the authors in each country, with other institutions in the same country, or with another institution in different countries, indicate that a "local cooperation." In table, "local" means that the cooperation took place in the same country and at the same university, "national" 
refers to the cooperation between researchers took place in the same country, but in different universities. And "International", it means that the cooperation between researchers took place in different countries and, consequently, in different universities.

Table 5. Ranking of countries

\begin{tabular}{|c|c|c|c|c|c|c|c|c|c|}
\hline Country & International & $\%$ & National & $\%$ & Local & $\%$ & $\begin{array}{c}\text { Without } \\
\text { Cooperation }\end{array}$ & $\%$ & Total \\
\hline USA & 35 & 0.20 & 37 & 0.24 & 43 & 0.21 & 62 & 0.35 & 177 \\
\hline England & 15 & 0.32 & 12 & 0.02 & 1 & 0.26 & 19 & 0.40 & 47 \\
\hline Germany & 10 & 0.26 & 8 & 0.23 & 9 & 0.21 & 12 & 0.31 & 39 \\
\hline Canada & 9 & 0.27 & 8 & 0.24 & 8 & 0.24 & 8 & 0.24 & 33 \\
\hline Italy & 10 & 0.34 & 6 & 0.21 & 6 & 0.21 & 7 & 0.21 & 29 \\
\hline China & 7 & 0.27 & 9 & 0.31 & 8 & 0.35 & 2 & 0.08 & 26 \\
\hline France & 7 & 0.27 & 5 & 0.23 & 6 & 0.19 & 8 & 0.31 & 26 \\
\hline Taiwan & 3 & 0.13 & 9 & 0.33 & 8 & 0.38 & 4 & 0.17 & 24 \\
\hline India & 3 & 0.14 & 11 & 0.14 & 3 & 0.50 & 5 & 0.23 & 22 \\
\hline Belgium & 11 & 0.52 & 8 & 0.05 & 1 & 0.38 & 1 & 0.05 & 21 \\
\hline Netherlands & 9 & 0.45 & 2 & 0.10 & 2 & 0.10 & 7 & 0.35 & 20 \\
\hline Brazil & 4 & 0.20 & 8 & 0.35 & 7 & 0.40 & 1 & 0.05 & 20 \\
\hline Australia & 2 & 0.14 & 4 & 0.07 & 1 & 0.29 & 7 & 0.50 & 14 \\
\hline Switzerland & 1 & 0.25 & 1 & 0.08 & 2 & 0.33 & 8 & 0.33 & 12 \\
\hline
\end{tabular}

Source: Data analysis was conducted by the authors using Gelphi software

In terms of percentage, The United States leads again the ranking with 177 scientific articles, 35\% without cooperation, 21\% local cooperation, 24\% national cooperation, and $20 \%$ international cooperation. The country with the highest of international cooperation in percentage is Belgium (52\%). While the Japan has the largest number of articles without cooperation $(67 \%)$.

\subsection{Institutions}

Table 6 demonstrates articles distribution among institutions (universities). The University of Alberta, Canada, is first in the number of citations and in thirteenth position in the ranking of articles. However, Katholieke Leuven University, in Belgium, is the first university in the ranking of articles with 13 publications, occupying the nineth position in the number of citations.

Table 6. Ranking of institutions

\begin{tabular}{|c|c|c|c|c|c|c|}
\hline Universities & Country & Citations & Articles & $\begin{array}{c}\text { Ranking } \\
\text { Articles }\end{array}$ & $\begin{array}{c}\text { Citations } \\
\text { Articles }\end{array}$ & $\begin{array}{c}\text { Ranking } \\
\text { Citations } \\
\text { Articles }\end{array}$ \\
\hline Univ. Alberta & Canada & 1168 & 4 & 13 & 292.0 & 6 \\
\hline Natl Inst. Nanotechnol & Canada & 1120 & 1 & 116 & 1120.0 & 1 \\
\hline New York University & USA & 832 & 3 & 24 & 277.3 & 7 \\
\hline Univ. Washington & USA & 552 & 1 & 117 & 552.0 & 2 \\
\hline Univ. Calif. Los Angeles & USA & 509 & 3 & 25 & 169.7 & 10 \\
\hline Anal Grp Econ & USA & 449 & 1 & 118 & 449.0 & 3 \\
\hline Harvard University & USA & 443 & 5 & 7 & 88.6 & 18 \\
\hline University of Wales & Wales & 375 & 1 & 119 & 375.0 & 4 \\
\hline Katholieke Univ. Leuven & Belgium & 348 & 13 & 1 & 26.8 & 101 \\
\hline
\end{tabular}




\begin{tabular}{ccccccc}
\hline University of Penn & USA & 315 & 2 & 47 & 157.5 & 11 \\
\hline Zeneca Agrochem & England & 301 & 1 & 120 & 301.0 & 5 \\
\hline University of Minnesota & USA & 278 & 6 & 4 & 46.3 & 40 \\
\hline University of Michigan & USA & 238 & 5 & 8 & 47.6 & 37 \\
\hline Massachusetts Gen. Hosp. & USA & 225 & 1 & 121 & 225.0 & 8 \\
\hline University of Maryland & USA & 213 & 2 & 48 & 106.5 & 17 \\
\hline
\end{tabular}

Source: Data analysis was conducted by the authors using Gelphi software

Table 7 shows the level of cooperation. The universities in Belgium and England do all their research in cooperation. In the case of the University of Belgium, $46 \%$ of its research is either local or international. We highlight the dynamics of American universities, which are on this list, all working in some way in international cooperation, except for the universities of Missouri and, surprisingly, Harvard. Asian universities stand out, with four universities represented on the list.

Table 7. Ranking of cooperation among universities

\begin{tabular}{ccccccc}
\hline Author affiliation & Country & International & National & Local & $\begin{array}{c}\text { Without } \\
\text { cooperation }\end{array}$ & Total \\
\hline Katholieke Univ. Leuven & Belgium & 0.46 & 0.08 & 0.46 & 0.00 & 13 \\
\hline University SUSSEX & England & 0.13 & 0.00 & 0.88 & 0.00 & 8 \\
\hline Duke University & USA & 0.43 & 0.39 & 0.14 & 0.14 & 7 \\
\hline University of Minnesota & USA & 0.50 & 0.33 & 0.00 & 0.17 & 6 \\
\hline Natl Taiwan University & Taiwan & 0.50 & 0.00 & 0.50 & 0.00 & 6 \\
\hline University of Missouri & USA & 0.00 & 0.33 & 0.00 & 0.67 & 6 \\
\hline University of Michigan & USA & 0.20 & 0.00 & 0.00 & 0.80 & 5 \\
\hline Norman Consulting & England & 0.00 & 0.00 & 0.00 & 1.00 & 5 \\
\hline Tufts University & USA & 0.20 & 0.60 & 0.00 & 0.20 & 5 \\
\hline CNR & Italy & 0.60 & 0.40 & 0.00 & 0.00 & 5 \\
\hline Harvard University & USA & 0.00 & 0.40 & 0.20 & 0.40 & 5 \\
\hline Foley \& Lardner & USA & 0.40 & 0.00 & 0.20 & 0.40 & 5 \\
\hline Natl University Singapore & Singapore & 0.50 & 0.35 & 0.00 & 0.35 & 4 \\
\hline Natl Cheng Kung University & Taiwan & 0.25 & 0.35 & 0.25 & 0.25 & 4 \\
\hline Natl Yang Ming University & Taiwan & 0.00 & 0.75 & 0.00 & 0.25 & 4 \\
\hline
\end{tabular}

Source: Data analysis was conducted by the authors using Gelphi software

\subsection{Network Analysis - metrics}

To expand the analysis of this study, the authors used the indicators of modularity, degree, weighted average degree, degree of intermediation, degree of proximity, giant component, and PageRank, with the intention of contributing to the analyses and findings necessary to respond to the research problem.

According to Blondel et al. [57], the modularity metric is the most used to identify cooperation clusters. This metric has an algorithm that makes it possible to group nodes that are more densely connected than in the rest of the network and that define communities according to the strength of their connections.

Therefore, once the network is defined with its nodes and edges, there is a wide variety of metrics that can be used to evaluate not only the elements (composition) of a network, but also the way they behave when interconnected. The main algorithms and functions used in SNA and adopted in this work are degree centrality [36,58], closeness centrality [58], betweenness centrality [36], PageRank [59], and eigenvector centrality [60]. 
Table 8 shows all network statistics extracted from Gephi software and treated with Excel resources for the top 15 countries.

Table 8. Ranking of cooperation among universities

\begin{tabular}{cccccc}
\hline Country & Degree & PageRank's & $\begin{array}{c}\text { Eigenvector } \\
\text { centrality }\end{array}$ & Triangles & $\begin{array}{c}\text { Clustering } \\
\text { Coefficient }\end{array}$ \\
\hline USA & 25 & 0.102 & 1 & 33 & 0.110 \\
\hline England & 11 & 0.043 & 0.546 & 15 & 0.273 \\
\hline Saudi Arabia & 13 & 0.042 & 0.703 & 28 & 0.359 \\
\hline Germany & 9 & 0.040 & 0.413 & 7 & 0.194 \\
\hline Belgium & 10 & 0.039 & 0.538 & 16 & 0.356 \\
\hline Italy & 10 & 0.037 & 0.579 & 14 & 0.311 \\
\hline Netherlands & 6 & 0.025 & 0.388 & 8 & 0.533 \\
\hline Denmark & 6 & 0.024 & 0.377 & 7 & 0.467 \\
\hline Iran & 8 & 0.024 & 0.530 & 22 & 0.786 \\
\hline Canada & 5 & 0.023 & 0.251 & 2 & 0.200 \\
\hline China & 5 & 0.021 & 0.277 & 4 & 0.400 \\
\hline France & 5 & 0.021 & 0.304 & 4 & 0.400 \\
\hline Bahrain & 7 & 0.021 & 0.416 & 21 & 1.000 \\
\hline Jordan & 7 & 0.021 & 0.416 & 21 & 1.000 \\
\hline Kuwait & 7 & 0.021 & 0.416 & 21 & 1.000 \\
\hline
\end{tabular}

Source: Data analysis was conducted by the authors using Gelphi software

The United States is the country with the largest representation within the network formed, as they meet, among others, the following criteria: degree centrality, as it has significant representativeness in the network formed (25), demonstrates its popularity and ability to disseminate information influencing the connected countries with it in the network; eigenvector centrality represents how the country impact other actors in terms of the global or total network structure [60] and PageRank, which is an algorithm used in SNA with a similar function to the others of centrality is used to indicate the highly connection of the country with many other countries in the network. This data analysis may also be viewed in the network design (figure 3 ) and these associations may be applied for all countries listed on the table. 


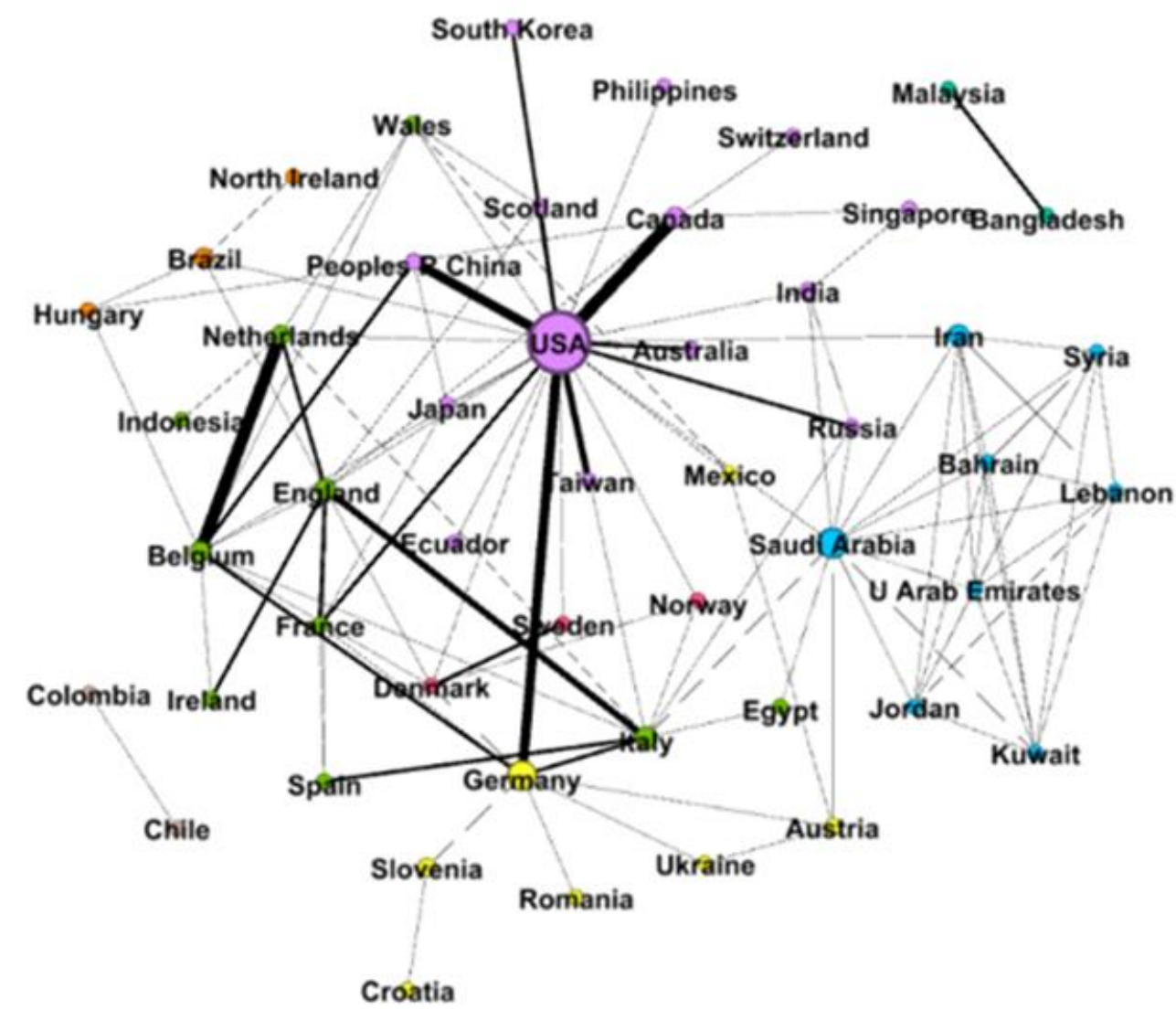

Figure 3. Country network. Source: Data analysis was conducted by the authors using Gelphi software

\section{Discussion}

This study analyzed the scientific production on the theme of technological cooperation networks and patents in biotechnology, based on bibliometrics with network analysis. We visualized how researchers, universities, and countries are strategically organized to conduct their research in the field of biotechnology.

Initially identify that the theme "technological cooperation networks" has been growing over the years and consolidating itself in the scientific literature, particularly in the biotechnology sector, where companies use cooperation to gain efficiency, especially in their R\&D processes. In this arrangement, investments in R\&D are an important tool to increase the innovative potential of an industry or region.

When policy makers provide support for research and development, they expect funded companies to reinforce additional investments in their own R\&D, create new opportunities for mutual learning, aiming to increase the results of research and the innovative potential of companies [61]. This phenomenon occurs since there is a demand due to the sector's dynamics to be continuously launching innovative products.

The United States leads general scientific production, with $27 \%$ of the world's production. Second is England (7\%), followed by Germany (6\%) and Canada (5\%). Regarding the number of citations, The United States remains the frontrunner with $39 \%$ of total number, Canada appears with 14\%, England with $6 \%$ and Germany with $5 \%$.

Another interesting aspect to note is the number of citations by the authors that stand out in their respective areas, as this is an indicator of productivity, as recommended by Lotka's law. In the technical area, Knox et al. [41] appears with 13 more researchers from the University of Alberta and 1088 citations. In the management area Schilling and Phelps [42] appears with 1377 citations, and Zucker et al. [43] with 1336 citations. 
In the analysis of cooperation networks between countries, The United States' role as the main hub in the publication of scientific articles related to the biotechnology field is clear. Concerning the field of studies on innovation, the actors with high centrality can be considered the most 'open innovators' [56]. The United States has a global strategic role, maintaining strong research connections from scientific articles in cooperation by its institutions with countries such as Canada, China, and Germany, among others.

In turn, Europe also forms a hub together with Germany as one of the most representative actors in this block, maintaining research connections with Italy, England, Holland, and Belgium countries. In this sense, the structural position of actors within these network systems is an important indicator of their capacity for open innovation $[52,53]$.

From the analysis of the cooperation network between countries and universities, one can ascertain the strategy that each country adopts in the development of research in the field of biotechnology and The United States again leads with approximately $70 \%$ of its research developed in cooperation internationally $(20 \%)$, nationally $(24 \%)$ and locally (21\%). These figures demonstrate a balance in North American participation. Germany and Canada have a similar balance. The exception is for England, which works with $60 \%$ of its research in a cooperative way, $32 \%$ internationally and only $2 \%$ nationally. Despite of this scenario, England strategy clearly demonstrated its open globally.

In cooperation among universities, seven American universities appear as highly cooperative institutions, three universities in Taiwan and two in England. And North America predominance is unmistakable, and the numbers are somewhat balanced.

We concluded that in the biotechnology sector naturally work in an environment in which network cooperation predominates, corroborating with findings of Casper [62]; Gay and Dousset [63]; Powell and Sandholz [64]. It means that R\&D process can be performed more efficiently in a lowest possible cost and time. The path direction is in the search for new resources that complement skills and competences. Cooperation is also in favor of new knowledge acquisition and access to complementary resources [65], thus improving the allocation of investments and contributing to the innovative performance of the actors involved $[66,67]$.

\section{Conclusions}

Under cooperative aspects, universities and research centers play an essential role in the process because the greater intensity of cooperation, the higher gains for all actors involved. The role of universities as knowledge transfer institutions is fundamental to innovation ecosystems, making the regions more representative in innovation field $[55,68,69,70]$.

The study has some limitations in analyzing only a specific period. However, it would be interesting to evaluate other segments such as nanotechnology for future studies, in other regions identifying their characteristics and specificities.

Author Contributions: All authors had relevant contributions to the conception of the paper, according to their research interests and expertise. "Conceptualization, J.-M.S.A. and P.-R.C.; methodology, J.-M.S.A. and P.-R.C.; software, J.-M.S.A. and P.-R.C.; validation, J.-M.S.A. and P.-R.C.; formal analysis, J.-M.S.A. and P.-R.C.; investigation, J.-M.S.A. and P.-R.C.; resources, J.-M.S.A. and P.-R.C.; data curation, J.-M.S.A. and P.-R.C.; writing-original draft preparation, J.-M.S.A. and P.-R.C.; writing-review and editing, J.-M.S.A.; P.-R.C.; A.P.; C.-T.K.; G.-S.P.; A.-F.P.; L.V.; M.-R.M; A.-M.S.; visualization, J.-M.S.A.; P.-R.C.; A.P.; C.-T.K.; G.-S.P.; A.-F.P.; L.V.; M.-R.M; A.-M.S.; supervision, J.M.S.A.; P.-R.C.; A.P.; C.-T.K.; G.-S.P.; A.-F.P.; L.V.; M.-R.M; A.-M.S.; project administration, J.-M.S.A and P.-R.C.;" All authors have read and agreed to the published version of the manuscript.

Funding: This research received no external funding.

Informed Consent Statement: Informed consent was obtained from all subjects involved in the study. 
Data Availability Statement: Data is not publicly available, though the data may be made available on request from the corresponding author.

Conflicts of Interest: The authors declare no conflicts of interest.

\section{References}

1. Pisano, G. Profiting from innovation and the intellectual property revolution. Res Policy, 2006, 35, 1122-1130.

2. Yun, W. A. N. G.; Wenhsiang, L. A. I. Exploring the Influential Factors of Cluster Cooperation in Taiwan's Biotechnology Industry. J Soc Adm Sci, 2017, 4, 146-165.

3. Estrella, A.; Bataglia, W. A influência da rede de alianças no crescimento das empresas de biotecnologia de saúde humana na indústria brasileira. Organ Soc, 2013, 20, 321-339.

4. Frenken, K.; Ponds, R.; Van Oort, F. The citation impact of research collaboration in science-based industries: A spatial-institutional analysis. Pap Reg Sci, 2010, 89, 351-271.

5. Fernald, K.; Pennings, E.; Claassen, E. Biotechnology commercialization strategies: Risk and return in interfirm cooperation. J Prod Innovat Manag, 2015, 32, 971-996.

6. Belter, C. W.; Seidel, D. J. A bibliometric analysis of climate engineering research. Wires Clim Chang, 2013, 4, 417-427.

7. Du, H.; Li, N.; Brown, M. A.; Peng, Y.; Shuai, Y. A bibliographic analysis of recent solar energy literatures: The expansion and evolution of a research field. Renew Energ, 2014, 66, 696-706.

8. Fahimnia, B.; Sarkis, J.; Davarzani, H. Green supply chain management: A review and bibliometric analysis. Int J Prod Econ, 2015, 162, 101-114.

9. Zbuchea, A.; Pînzaru, F.; Busu, M.; Stan, S. O.; Bârgăoanu, A. Sustainable knowledge management and its impact on the performances of biotechnology organizations. Sustainability, 2019, 11, 359.

10. Powell, W. W.; Koput, K. W.; Smith-Doerr, L. Interorganizational collaboration and the locus of innovation: Networks of learning in biotechnology. Admin Sci Quart, 1996, 41, 116-145.

11. Chang, Y. C. Benefits of co-operation on innovative performance: evidence from integrated circuits and biotechnology firms in the UK and Taiwan. RED Manage, 2003, 33(4), 425-437.

12. Gittelman, M. National institutions, public-private knowledge flows, and innovation performance: A comparative study of the biotechnology industry in the US and France. Res Policy, 2006, 35, 1052-1068.

13. Balestrin, A.; Verschoore, J. Redes de Cooperação Empresarial: Estratégias de Gestão na Nova Economia, 2nd ed.; Bookman Editora: Porto Alegre, Brazil, 2016, pp. 37-45.

14. Ahuja, G. Collaboration networks, structural holes, and innovation: A longitudinal study. Admin Sci Quart, 2000, 45, 425-455.

15. Arya, B.; Lin, Z. Understanding collaboration outcomes from an extended resource-based view perspective: The roles of organizational characteristics, partner attributes, and network structures. J Manage, 2007, 33, 697-723

16. Chesbrough, H. W. Open innovation: The new imperative for creating and profiting from technology, 1st ed. Harvard Business School Press, Boston, Massachusetts, 2003, pp. 4-13.

17. Chesbrough, H.; Vanhaverbeke, W.; West, J. Open innovation: Researching a new paradigm, 1st ed. Oxford University Press, New York, USA, 2006, pp. 15-82.

18. Baba, Y.; Shichijo, N.; Sedita, S. R. How do collaborations with universities affect firms' innovative performance? The role of "Pasteur scientists" in the advanced materials field. Res Policy, 2009, 38, 756-764.

19. McKelvey, M.; Zaring, O.; Ljungberg, D. Creating innovative opportunities through research collaboration: An evolutionary framework and empirical illustration in engineering. Technovation, 2015, 39, 26-36.

20. Bogers, M.; Chesbrough, H.; Moedas, C. Open innovation: research, practices, and policies. Calif Manage Rev, $2018,60,5-16$.

21. Santoro, G.; Ferraris, A.; Giacosa, E.; Giovando, G. How SMEs engage in open innovation: a survey. J Knowl Econ, 2018, 9, 561574 .

22. Chesbrough, H.; Bogers, M. Explicating open innovation: Clarifying an emerging paradigm for understanding innovation. In New Frontiers in Open Innovation, draft version. Oxford: Oxford University Press, 2014, Forthcoming, pp. 3-28. https://papers.ssrn.com/sol3/papers.cfm?abstract_id=2427233

23. Belderbos, R.; Carree, M.; Lokshin, B. Complementarity in R\&D cooperation strategies. Rev Ind Organ, 2006, $28,401-426$.

24. Bengtsson, M.; Sölvell, Ö. Climate of competition, clusters, and innovative performance. Scand J Manag, 2004, 20, $225-244$.

25. Pittaway, L.; Robertson, M.; Munir, K.; Denyer, D.; Neely, A. Networking, and innovation: a systematic review of the evidence. Int J Manag Rev, 2004, 5, 137-168.

26. Lin, C. C.; Yang, C. H.; Shyua, J. Z. A comparison of innovation policy in the smart grid industry across the pacific: China and the USA. Energ Policy, 2013, 57, 119-132.

27. Torres-Freire, C.; Golgher, D.; Callil, V. Biotecnologia em saúde humana no Brasil: produção científica e pesquisa e desenvolvimento. CEBRAP, 2014, 98, 69-93. https://doi.org/10.1590/S0101-33002014000100005

28. Etzkowitz, H.; Leydesdorff, L. The dynamics of innovation: from National Systems and "Mode 2" to a Triple Helix of university-industry-government relations. Res Policy, 2000, 29, 109-123.

29. Rentocchini, F.; D’Este, P.; Manjarrés-Henríquez, L.; Grimaldi, R. The relationship between academic consulting and research performance: Evidence from five Spanish universities. Int J Ind Organ, 2014, 32, 70-83.

30. Narin, F.; Olivastro, D.; Stevens, K. A. Bibliometrics/theory, practice, and problems. Evaluation Rev, 1994, 18, 65-76. 
31. LINGUEE. Online Dictionary Linguee introduces 218 new language pairs. Available at https://www.linguee.com/ accessed on 25 February 2021.

32. Bastian, M.; Heymann, S.; Jacomy, M. Gephi: an open-source software for exploring and manipulating networks. In Third international AAAI conference on weblogs and social media, San Jose Californica, USA, 17-20 May 2009, 3, pp. $361-362$.

33. de Paulo, A. F.; Porto, G. S. Solar energy technologies and open innovation: A study based on bibliometric and social network analysis. Energ Policy, 2017, 108, 228-238.

34. Page, L.; Brin, S.; Motwani, R.; Winograd, T. The PageRank citation ranking: Bringing order to the web. Stanford InfoLab, 1999, 1, 1-14. http://ilpubs.stanford.edu:8090/422/

35. Jackson, M. O. Social and economic networks., 1st ed. Princeton university press. New Jersey, USA, 2010; pp. 77-107.

36. Newman, M. Epidemics on networks. Oxford Scholarship Online, 2010. Doi10.1093/acprof:oso/9780199206650.003.0017

37. Balancieri, R.; Bovo, A. B.; Kern, V. M.; Pacheco, R. C. D. S.; Barcia, R. M. (2005). A análise de redes de colaboração científica sob as novas tecnologias de informação e comunicação: um estudo na Plataforma Lattes. Cienc Inf, 2005, 34, 64-77.

38. Newman, M. E.; Girvan, M. Finding and evaluating community structure in networks. Phys Rev E, 2004, $69,026113$.

39. Capaldo, A. Network structure and innovation: The Leveraging of a dual network as a distinctive relational capability. Strategic Manage J, 2007, 28, 585-608.

40. OECD. A framework of biotechnology statistics, 2005. http://www.oecd.org/sti/inno/34935605.pdf. Accessed on 25 February 2021

41. Knox, C.; Law, V.; Jewison, T.; Liu, P.; Ly, S.; Frolkis, A.; ... Wishart, D. S. DrugBank 3.0: a comprehensive resource for 'omics' research on drugs. Nucleic Acids Res, 2010, 39, D1035 - D1041.

42. Schilling, M. A.; Phelps, C. C. Interfirm collaboration networks: The impact of large-scale network structure on firm innovation. Manage Sci, 2007, 53, 1113-1126.

43. Zucker, L. G.; Darby, M. R.; Armstrong, J. S. Commercializing knowledge: University science, knowledge capture, and firm performance in biotechnology. Manage Sci, 2002, 48, 138-153.

44. Giddings, G.; Allison, G.; Brooks, D; Carter, A. Transgenic plants as factories for biopharmaceuticals. Nat Biotechnol, 2000, 18(11), 1151-1155.

45. Baylis, A. D. Why glyphosate is a global herbicide: strengths, weaknesses, and prospects. Pest Manag Sci, 2000, 56, 299-308.

46. Gittelman, M.; Kogut, B. Does good science lead to valuable knowledge? Biotechnology firms and the evolutionary logic of citation patterns. Manage Sci, 2003, 49, 366-382.

47. Blumenthal, D.; Causino, N.; Campbell, E.; Louis, K. S. Relationships between academic institutions and industry in the life sciences - an industry survey. New Engl J Med, 1996, 334(6), 368-374.

48. Ziedonis, R. H. Do not fence me in: Fragmented markets for technology and the patent acquisition strategies of firms. Manage Sci, 2004, 50, 804-820.

49. Shane, S. Selling university technology: Patterns from MIT. Manage Sci, 2002, 48, 122-137.

50. Broothaerts, W.; Mitchell, H. J.; Weir, B.; Kaines, S.; Smith, L. M.; Yang, W.; ... Jefferson, R. A. Gene transfer to plants by diverse species of bacteria. Nature, 2005, 433, 629-633.

51. Maia, M. D. F. S.; Caregnato, S. E. Co-authorship as an indicator of scientific collaboration network. Perspect Cienc Inf, 2008, 3 , 18-31.

52. Belussi, F.; Sammarra, A.; Sedita, S. R. Learning at the boundaries in an "Open Regional Innovation System": A focus on firms' innovation strategies in the Emilia Romagna life science industry. Res Policy, 2010, 39, 710-721.

53. Plunket, A.; Cassi, L.; Gallié, E. P.; Mérindol, V. Breakthrough inventions, firm characteristics, and technological sector dynamics. In 35th DRUID Celebration Conference, Barcelona, Spain, 2013, 17-19.

54. Everett, M.; Borgatti, S. P. Ego network betweenness. Soc networks, 2005, 27, 31-38.

55. Owen-Smith, J.; Powell, W. W. Knowledge networks as channels and conduits: The effects of spillovers in the Boston biotechnology community. Organ Sci, 2004, 15, 5-21.

56. Fleming, L.; Waguespack, D. M. Brokerage, boundary spanning, and leadership in open innovation communities. Organ Sci, 2007, 18, 165-180.

57. Blondel, V. D.; Guillaume, J. L.; Lambiotte, R.; Lefebvre, E. Fast unfolding of communities in large networks. J Stat Mech-Theory E, 2008, 10, P10008.

58. Zhang, Y.; Li, H. Innovation search of new ventures in a technology cluster: the role of ties with service intermediaries. Strateg Manage J, 2010, 31, 88-109.

59. Brin, S.; Page, L. Reprint of: The anatomy of a large-scale hypertextual web search engine. Comp Netw, 2012, 56, $3825-3833$.

60. Hanneman, R. A.; Riddle, M. Introduction to social network methods. University of California, Riverside. Riverside, CA, 2005; http://faculty.ucr.edu/ hanneman/

61. Buchmann, T.; Kaiser, M. The effects of R\&D subsidies and network embeddedness on R\&D output: evidence from the German biotech industry. Ind Innov, 2019, 26, 269-294.

62. Casper, S. How do technology clusters emerge and become sustainable? social network formation and inter-firm mobility within the San Diego biotechnology cluster. Res Policy, 2007, 36, 438-455.

63. Gay, B.; Dousset, B. Innovation and network structural dynamics: Study of the alliance network of a major sector of the biotechnology industry. Res Policy, 2005, 34, 1457-1475. 
64. Powell, W. W.; Sandholtz, K. W. Amphibious entrepreneurs and the emergence of organizational forms. Strateg Entrep J, 2012, 6, 94-115.

65. Chesbrough, H. W.; Appleyard, M. M. Open innovation, and strategy. Calif Manage Rev, 2007, 50, 57-76.

66. Sampson, R. C. R\&D alliances, and firm performance: The impact of technological diversity and alliance organization on innovation. Acad Manage J, 2007, 50, 364-386.

67. Schilling, M. A. Technology shocks, technological collaboration, and innovation outcomes. Organ Sci, 2015, 26, 668-686.

68. Garnsey, E.; Heffernan, P. High-technology clustering through spin-out and attraction: The Cambridge case. Reg Stud, 2005, 39, 1127-1144.

69. Lawton Smith, H.; Leydesdorff, L. The Triple Helix in the context of global change: dynamics and challenges. Prometheus, 2014, 32, 321-336.

70. Reynolds, E. B.; Uygun, Y. Strengthening advanced manufacturing innovation ecosystems: The case of Massachusetts. Technol Forecast Soc, 2018, 136, 178-191. 